\title{
PENGARUH PHONOLOGICAL AWARENESSTERHADAP KEMAMPUAN PENYELESAIAN SOAL CERITA MATEMATIKA SISWA SEKOLAH DASAR
}

\author{
1) Een Ratnengsih \\ ${ }^{1)}$ Universitas Pendidikan Indonesia, Jln. Setiabudhi No.229 Bandung \\ E-mail: ratnengsih_een@upi.edu
}

\begin{abstract}
s
This research entitled "The Effect of phonological awareness for Problem Resolution Capability in Elementary School Math Stories". The purpose of this study was to determine the effect of phonological awareness component (semantic and syntactic) the ability of the completion of a story about math at the Grade 1 Elementary School. The achieve the research objectives, this research is using the exposure facto quantitative approach. The data collection in this study using a test technique with one retrieval, which tests math story problem resolution skills and phonological awareness skills test. The data was analyzed using path analysis. The samples in this study were 96 students of grade 1 elementary school in the District Antapani Bandung. The results show that phonological awareness components (semantics and syntax) and the combined partial both have a significant effect on the ability of the settlement effect story about the math of the completion of a story about math at the Elementary School (reading comprehension, mathematic computation, and comprehension).
\end{abstract}

Keywords : Phonological awareness, kemampuan penyelesaian soal cerita matematika

\section{A. PENDAhuluan}

Salah satu sasaran pendidikan adalah untuk memberi bekal pengetahuan dan kemampuan yang dapat berfungsi secara efektif dalam menjalani kehidupan dizaman yang semakin berkembang ini. Apa yang dipelajari dijenjang pendidikan formal diharapkan dapat memberikan manfaat praktis bagi siswa dalam kehidupannya sehari-hari. Oleh karena itu mata pelajaran yang dipelajari di sekolah seharusnya menjadi sesuatu hal yang disukai dan diminati oleh siswa, sehingga diharapkan siswa akan belajar dan memahami setiap mata pelajaran tersebut tanpa beban.

Matematika merupakan salah satu mata pelajaran yang dipelajari jenjang pendidikan formal. Meskipun pada kenyataannya mata pelajaran matematika masih sering menjadi hal yang sangat sulit dan tidak disukai siswa, hal ini sejalan dengan apa yang dikemukakan Rusffendi
(1991:34) matematika merupakan mata pelajaran yang kurang disenangi, dianggap sebagai ilmu yang sukar, ruwet dan memperdayakan. Akibatnya motivasi dan kemampuan yang ditampilkan dalam mata pelajaran ini cenderung tidak sesuai dengan potensi yang dimiliki siswa.

Berdasarkan hasil survey di Amerika Serikat dan Eropa menurut Geary (2004) terdapat $5 \%-8 \%$ siswa yang mengalami kesulitan belajar matematika atau mathematic learning difficulties dari jumlah populasi siswa Sekolah Dasar yang berada di kedua negara tersebut. Dari data yang diperoleh hasil survei tersebut jelas merupakan permasalahan yang meski disikapi. Semua siswa yang mengalami kesulitan belajar matematika tersebut berhak memperoleh pendidikan yang sesuai dengan kebutuhan belajarnya.

Paradigma baru menuntut layanan pendidikan yang diberikan harus inkusif, dimana layanan pendidikan yang diberikan 
harus berpusat pada siswa dan memenuhi kebutuhan belajar siswa, termasuk siswa yang mengalami kesulitan belajar matematika. Layanan pendidikan bagi siswa berkesulitan belajar tidak mesti belajar di seting segregasi, terlebih Sekolah Khusus (SLB) untuk kategori anak berkesulitan belajar spesifik matematika masih langka ditemui. Dengan paradigma baru siswa berkesulitan belajar matematika dapat memperoleh layanan pendidikan yang sesuai dengan kebutuhannya di sekolah regular.

Salah satu pembahasan yang dipelajari dalam mata pelajaran matematika di jenjang Sekolah Dasar adalah problem solving, antara lain pembahasan tentang penyelesaian soal cerita. Menurut hasil penelitian Fitriani (2011:3) kesulitan yang seringkali muncul pada siswa sokalah dasar berkaitan dengan penyelesaian soal cerita matematika yaitu : (1) Siswa tidak dapat memahami kalimat dalam soal cerita; (2) Siswa tidak dapat menarik beberapa informasi yang terdapat dalam soal cerita; (3) Siswa tidak dapat menentukan apa inti permasalahan yang ditanyakan dalam soal cerita; (4) Siswa tidak dapat menentukan sendiri langkah penyelesaian soal cerita matematika; (5) Siswa tidak dapat menyimpulkan jawaban soal cerita matematika. Hal ini senada dengan pendapat Gooding (2009) yang menyatakan bahwa berdasarkan beberapa hasil peneltian terdapat lima kategori penyebab kesulitan yang berkaitan dengan masalah kata dalam matematika yaitu : (1) Kemampuan membaca dan pemahaman bahasa yang digunakan dalam masalah matematika; (2) memahami dan mengimajinasikan konteks dalam masalah matematika; (3) menyusun kalimat matematika yang berkaitan dengan masalah matematika; (4) menentukan perhitungan matematika; dan (5) mengiterpretasikan jawaban dengan pertanyaan yang dimaksud.

Permasalahan lain muncul tidak hanya disebabkan karena faktor internal melainkan juga disebabkan faktor eksternal yaitu faktor penyebab diluar diri anak. Menurut Lovitt (1989:147) terdapat tiga kelompok penyebab seorang siswa dalam bidang studi matematika mengalami kegagalan, yaitu ;(1) Kegagalan yang berhubungan dengan penyebab lain (correlated failure), (2) Kegagalan karena system pengajaran yang digunakan (instructional failure), dan (3) kegagalan dari dalam individu (individual failure).

\section{B. KAJIAN LITERATUR}

Salah satu komponen yang harus dikuasai dalam menyelesaikan soal cerita matematika adalah kemampuan memahami permasalahan matematika. Kemampuan memahami permasalahan matematika akan berkaitan dengan kemampuan membaca pemahaman. Kemampuan membaca pemahaman menjadi faktor penting karena soal cerita matematika disajikan dalam bentuk soal bacaan kalimat. Berbicara masalah membaca pemahaman tentu akan terkait dengan pemahaman makna kata dan kalimat. Pemahaman kata dan kalimat sendiri tidak akan terlepas dari pembahasan bahasa. Menurut Bruner dalam Dahar (2005:106) bahwa bahasa adalah kunci perkembangan kognitif, karena bahasa merupakan alat komunkasi antar manusia. Untuk memahami konsepkonsep yang ada diperlukan bahasa. Berbicara bahasa maka akan terkait dengan persoalan bunyi dimana prosesnya dilalui salah satunya lewat sensori auditoris. Komponen bahasa menjadi penting dalam matematika senada dengan pendapat para ahli (Robinson, Manchetti, dan Torgesen : 2002) yang menggunakan proses pemerolehan komponen bahasa dengan istilah phonological processing.

Istilah phonological processing menurut Lancaster dan Pope (1997:4) operasi mental yang diaplikasikan dalam bicara untuk merubah bentuk atau urutan bunyi. Dalam phonological processing terdapat tiga komponen, yaitu : (1) 
Kesadaran Fonologis (Phonological Awareness); (2) Kecepatan Penamaan (Rapid Naming) dan (3) Kemampuan Mengingat Fonologi (Phonological Memory). Masing-masing dikembangkan secara terpisah (Wagner, Torgensen \& Rashotte, 1999).

Salah satu komponen yang terdapat dalam phonological processing adalah kesadaran fonologis (Phonological Awareness). Menurut Torgessen dan Wagner (1998) Phonoloycal Awarenes adalah sensitivitas atau kesadaran eksplisit seseorang yang meliputi kemampuan melihat, memikirkan atau memanipulasi struktur bunyi dari kata-kata dalam bahasanya. Apabila melihat pengertian phonological awareness dan phonological processing memiliki memiliki kajian yang sama yaitu persoalan bunyi. Phonological awerrenes merupakan bagian dari phonological processing seperti yang dikemukakan (Wagner, Torgensen \& Rashotte, 1999). Oleh karena itu pembahasan mengenai phonological processing dapat juga menggunakan istilah phonological awerreness. Dalam phonological awareness terdapat beberapa komponen antara lain komponen fonem, morfem, semantik, sintasksis, prosidi dan pragmatik.

Berkaitan dengan phonological awareness Robinson, Menchetti, dan Torgesen (2002) menyatakan bahwa kegagalan individu dalam belajar matematika sangat ditentukan oleh kemampuan individu untuk melakukan proses fonologis, yaitu kemampuan operasi mental yang diaplikasikan dalam bicara untuk merubah bentuk bunyi atau urutan bunyi. Hambatan dalam phonological processing akan menyebabkan siswa mengalami kesulitan dalam penguasaan komponen bahasa. Penguasaan komponen bahasa menyebabkan siswa mengalami hambatan dalam perkembangan isi dan bentuk bahasa. Dan jika siswa mengalami hambatan dalam perkembangan isi dan bentuk bahasa akibatnya siswa akan mengalami kesulitan dalam berbagai bidang pelajaran, termasuk belajar membaca dan matematika Okamoto dan Case dalam Santoso (2008).

Hasil penelitian yang dilakukan oleh Budi Santoso (2008) berkaitan dengan phonological processing pada anak usia pra sekolah yang memiliki kemampuan phonological processing rendah dan tinggi menunjukan bahwa terdapat perbedaan yang signifikan dari kedua kelompok tersebut. Dimana jika kemampuan phonological processing siswa rendah maka kemampuan keterampilan dasar matematika siswa tersebut tidak akan tinggi, sebaliknya jika kemampuan phonological processing siswa tinggi maka keterampilan matematika siswa tersebut juga tidak akan rendah. Adapun kemampuan phonological processing yang diungkap dalam penelitian ini hanya pada tahap dasar yaitu penguasaan komponen bahasa pada aspek fonem dan morfem.

Phonological awareness sebagai penguasaan komponen bahasa yang didalamya berhubungan dengan perkembangan isi dan bentuk bahasa memiliki pengaruh dan peran penting dalam kemampuan matematika temasuk salah satunya penyelesaian soal cerita matematika bagi siswa sekolah dasar. Komponen semantik dan sintaksis diduga memberikan pengaruh terhadap kemampuan penyelesaian soal cerita matematika, hal ini senada dengan pernyataan yang dikemukakan Lancaster dan Pope (1997) bahwa pengaruh Phonological proccesing aspek semantik dan sintaksis akan menentukan pemahaman struktur semantik dan sintaksis dalam struktur konsep matematika, Struktur konsep matematika terdiri dari; (1) prinsip-prinsip dalam matematika, (2) prosedur-prosedur dalam matematika, dan (3) hubungan-hubungan dalam matematika. 
Penyelesaian soal cerita matematika tidak akan terlepas dari penguasaan siswa tentang stuktur konsep matematika yang didalamnya terdiri dari penguasaan prinsip-prinsip, prosedur-prosedur dan hubungan-hubungan. Oleh karena itu penguasaan komponen semantik dan sintaksis menjadi sangat penting dalam penyelesaian soal cerita matematika. Namun untuk mengetahui komponen mana yang paling berpengaruh terhadap kemampuan penyelesaian soal cerita matematika dan seberapa besar pengaruhnya perlu dilakukan studi untuk mencari dan membuktikan kebenaran teori yang telah ada. Sehingga untuk mengatasi siswa yang mengalami hambatan dalam penyelesaian soal cerita matematika pada jenjang sekolah dasar harus diketahui dimana letak permasalahannya baik yang langsung maupun tidak.

Berangkat dari permasalahan di atas maka penelitian terhadap komponen phonological awarenes yang meliputi semantik dan sintaksis serta kemampuan meyelesaikan soal cerita sfesifik pada soal cerita sehari-hari dalam opersional penjumlahan dan pengurangan menjadi penting untuk diungkap. Materi soal cerita yang dipelajari pada subjek penelitian siswa kelas 1 Sekolah Dasar. Keterampilan menyelesaikan soal cerita yang dikaji mencakup tiga komponen yaitu : 1) membaca pemahaman (Reading comprehension); 2) Operasi bilangan (Computation) : 3) pemahaman matematika (Mathematic Comprehension). Adapun permasalahan pokok penelitian ini adalah " seberapa besar pengaruh komponen phonological awareness (semantik dan sintaksis) terhadap kemampuan menyelesaikan soal cerita matematika pada siswa kelas 1 sekolah dasar?"

Penelitian ini secara bertujuan untuk mengetahui apakah phonological awareness (semantik dan sintaksis) berpengaruh terhadap kemampuan menyelesaikan soal cerita matematika yang mencakup reading comprehension, computation dan mathematic comprehension pada siswa siswa kelas 1 sekolah dasar, sedangkan secara rinci penelitian ini bertujuan untuk : 1) Mengetahui besaran pengaruh komponen semantik dan sintaksis terhadap kemampuan reading comprehension,2) Mengetahui besaran pengaruh komponen semantik dan sintaksis terhadap kemampuan computation, 3) Mengetahui besaran pengaruh komponen semantik dan sintaksis terhadap kemampuan mathematic comprehension , 4) Mengetahui besaran pengaruh reading comprehension terhadap kemampuan mathematic comprehension, 5) Mengetahui besaran pengaruh computation terhadap kemampuan mathematic comprehension dan 6) Mengetahui besaran pengaruh komponen reading comprehension dan computation terhadap kemampuan mathematic comprehension

Hasil penelitian ini diharapkan meberika gambaran dan bukti empiris dari pengaruh Phonological Awareness (komponen semantik dan sintaksis) terhadap kemampuan penyelesaian soal cerita matematika, sehingga secara toritis dapat memberikan sumbangan berupa pengetahuan tentang hal di atas. Secara praktis diharapkan dapat memberikan masukan kepada guru tentang pengaruh phonological awareness yang terhadap proeses pembelajaran matematika di Sekolah Dasar terutama sebagai dasar dalam menangani siswa yang mengalami permasalahan belajar menyelesikan soal cerita matematika.

Kemampuan Phonological Awareness merupakan proses mental yang diaplikasikan dalam bicara untuk merubah bunyi atau urutan. Hal ini akan terkait dengan dengan kemampuan seseorang dalam memahami komponen bahasa. Penguasaan komponen bahasa meliputi : (1) fonem; (2) morfem; (3) semantik; (4) sintaksis; (5) prosidi dan (6) pragmatik. 
Dalam konteks matematika Menurut Lancaster dan Pope (1996:32) menyatakan Phonological awareess dalam kemampuan matematika dibagi menjadi tiga tahap, yaitu : (1) Pemahaman Struktur fonem dan morfem; (2) Pemahaman stuktur semantik dan sintaksis; dan (3) pemahaman struktur prosidi dan pragmatic.

Phonological awarenes tahap dasar, pada tahap ini didalamnya terdapat aspek pemahaman struktur fonem dan morfem. Dalam konteks belajar matematika, kemampuan ini akan menentukan kemampuan untuk mengkodekan bunyi ujaran angka dan kemampuan untuk menghubungkan antara bunyi ujaran angka dengan symbol angkanya.

Phonological awarrenes tahap lanjut, dalam tahap ini terdapat aspek semantik dan sintaksis, kemampuan phonological awareness ini menentukan pemahaman struktur semantik dan sintaksis dalam struktur konsep matematika, Struktur konsep matematika terdiri dari; (1) prinsip-prinsip dalam matematika, (2) prosedur-prosedur dalam matematika, dan (3) hubungan-hubugan dalam matematik.

Phonological awarrenes tahap akhir, terdapat aspek pemahaman prosodi dan pragmatik. Pada tahap ini menentukan pemahaman variasi dan kompleksitas logika matematika. Variasi dan kompleksitas logika matematika akan nampak pada apikasi matematika dalam interaksi social secara verbal.

Menurut Robinson, Mancheti dan Torgesen (2000:15) siswa yang mengalami hambatan memahami struktur semantik dan sintaksis akan mengalami kesulitan mememahmai stuktur semantik dan sintaksis dalam struktur konsep matematika yang meliputi pemahaman prinsip-prinsip prosedur-prosedur dan hubungan-hubungan dalam matematika.

Hasil studi yang sudah dilakukan oleh Perlwitz dalam Beardeu (1994) menyatakan bahwa siswa Sekolah Dasar kelas satu mengindikasikan bahwa aktivitas linguistik anak baik secara individu maupun keompok mempengaruhi pembentukan konsep matematika, sebaliknya tingkat kognisi anak mempengaruhi terhadap aktivitas linguistik siswa baik secara individu dan kelompok.

Hasil temuan Foster (2011) bahwa phonological awareness memberikan pengaruh terhadap skor matematika dasar. Pada anak-anak dengan hambatan perkembangan intelektual dengan phonological awareness rendah maka kemampuan matematika dasar menjadi rendah apabila tidak disertai dengan prevate speech yang baik.

Sejumlah peneliti (Hiebert \& Moser, 1983; De Corter \& Verschafel, 1981; Kintch \& Greeno, 1985; Morales, Shute, \& Pellegrino, 1985; Riley, Greeno, \& Heller, 1983, Vergnaud, 1982) dalam Prabawanto (2012) menyatakan bahwa salah satu aspek dari soal cerita yang berkenaan dengan penjumlahan dan pengurangan adalah struktrur semantiknya. Struktur ini diidentifikasi dalam beberapa tipe, yaitu yaitu merubah (change), menggabungkan (combine), membandingkan (compare), dan menyamakan (equalize). Selanjutnya Riley, dkk (1983) menyatakan bahwa keberhasilan menyelesaikan soal-soal cerita tergantung pada hubungan pengetahuan simantik yang ditemukan dalam masalah-masalah itu dan tergantung pula pada keterkaitan pengetahuan ini dengan langkah-langkah yang diperlukan dalam menyelesaikannya.

Tidak hanya unsur semantik ternyata sintaksis juga memiliki hubungan terkait keterampilan berbahasa. Menurut Pauslton dan Bruder dalam Ramli (1976:1) keterampilan berbahasa itu sangat erat hubunganya dengan penguasaan tatabahasa (sintaksis), karena tatabahasa itu meresap kepada empat keterampilan berbahasa, yaitu : mendengar, berbicara, membaca dan menulis 


\section{Faktor Penyebab Kesulitan Belajar}

Lovvitt (1989)

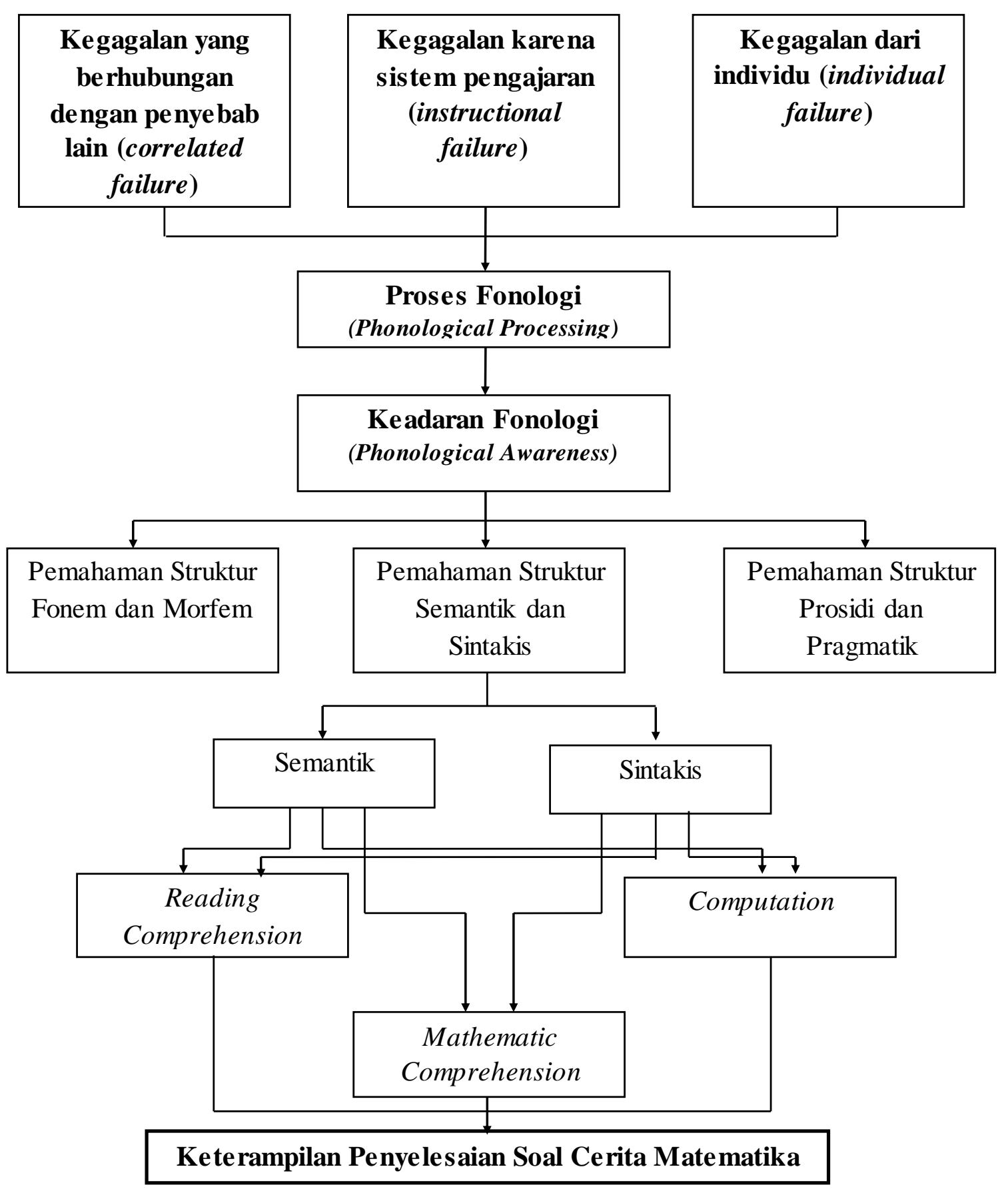

Gambar 1

Pengaruh Phonological Awareness Terhadap Kemampuan Penyelesaian Soal Cerita Matematika

(Dikembangkan berdasarkan Konsep dari Lovvit 1989; Robinon, Manchetti dan Torgesen 2002; Polya 2011; Goodstein 1987) 
Proses penyelesaian soal cerita dalam mata pelajaran matematika akan melibatkan komponen berbahasa. Menurut Goodstein dalam McLoughlin \& Lewis (1986 : 307) siswa harus memahami empat tahap dalam proses pengerjaaan pemecahan soal cerita, yaitu (1) Kemampuan mengidentifiksi operasi aritmatika yang diperlukan;

Mengidentifikasi bagian informasi yang relevan; (3) Terampil memformulasikan komputasi secara tepat dan sesuai; dan (4) Ketepatan dalam melakukan komputasi. Keempat tahap tersebut dikerucutkan ke dalam tiga kemampuan yaitu (1) Reading Comprehension dan (2) Computation dan (3) gabungan dari keduanya yaitu Mathematic Comprehension.

Membaca adalah suatu proses yang dilakukan serta dipergunakan oleh pembaca untuk memperoleh pesan, yang hendak disampaikan oleh penulis melalui media kata-kata/ bahasa tulisan (Hodgson dalam Tarigan, G.H. 2008: 7). Menurut Somantri ( 2005 : 115) Pemahaman terhadap suatu bacaan mencakup dua hal yaitu ekplisit dan implicit.

Komputasi merupakan operasi dasar dalam matematika. Keterampilan operasi dasar mutlak diperlukan siswa, karena akan banyak digunakan dalam menyelesaikan soal matematika yang lebih kompleks. Operasi Dasar dalam matematika akan sangat berkaitan dengan konsep. Menurut Herman (2010) menyatakan konsep adalah suatu ide atau gagasan yang dibentuk dengan memandang sifat-sifat yang sama dari sekumpulan eksemplar yang cocok. Dengan perkataan lain, jika kita dapat menemukan lebih dari satu fakta dari suatu ide maka kita menyebutnya sebagai suatu konsep. Terkait dengan pemahaman matematika, Mastie dan dan Jonson dalam Edi (2011:22) menyatakan bahwa pemahaman matematika terjadi bila orang mampu mengenali, menjelaskan dan menginterpretasikan sesuatu atau masalah yang dihadapi. Dengan demikian pemahaman matematika (Mathematic comprehension) adalah suatu kemampuan untuk mengerti dari susuatu yang tersaji, menterjemahkan atau memformulasikan dari suatu bentuk bentuk lain dalam katakata, angka maupun kalimat yang berbentuk penjelasan, ringkasan, prediksi dan hubungan sebab akibat.

\section{C.METODE}

Peneliti menggunakan menggunakan metode ekspos fakto dengan pendekatan kuantitatif. Populasi dalam penelitian ini adalah siswa kelas satu Sekolah Dasar di Kecamatan Atapani Kota Bandung baik yang mengalami kesulitan dalam menyelesaikan soal cerita matematika dan siswa yang tidak mengalami kesulitan menyelesaikan soal cerita matematika sebanyak 21 sekolah. Pengambilan sampel dalam penelitian ini dilakukan dengan menggunakan teknik cluster sampling sehingga jumlah sampel yang digunakan 4 sekolah dengan jumlah murid keseluruhan 96 orang. Teknik pengumpulan data dilakukan dengan teknik tes.

Adapun variable bebas dalam penelitian ini adalah phonological awareness, yaitu terdiri dari semantik dan sintaksis. semantik $\left(\mathrm{X}_{1}\right)$ adalah sensitivitas siswa dalam memahami makna atau arti dari sebuah kata berkaitan dengan soal yang didengarnya melalui indera pendengaran. Sintaksis $\left(\mathrm{X}_{2}\right)$ adalah sensitivitas siswa dalam memahami tata bahasa berupa kata yang disusun untuk membentuk sebuah kalimat atau berupa kalimat-kalimat yang disusun menjadi sebuah cerita melalui kata atau kalimat yang didengarnya. Variabel terikat dalam penelitian ini adalah kemampuan menyelesaikan soal cerita matematika sekolah dasar kelas 1 Sekolah Dasar yang mencakup reading comprehension $\left(\mathrm{Y}_{1}\right)$, computation $\left(\mathrm{Y}_{2}\right)$ dan mathematic comprehension $\left(\mathrm{Y}_{3}\right)$. 
Pengujian validitas empirik menggunakan rumus Pearson Product Moment. Sedangkan pengujian reliabilitas dilakukan dengan menggunakan rumus Alpha melalui bantuan program SPSS.

Adapun teknik analisis data yang digunakan dengan menghitung skor data berdasarkan data yang telah diambil di lapangan sesuai dengan kriteria yang telah ditentukan. Kemudian dilakukan analisis ststistik melalui uji analisis jalur (Path Analisis). Hasil pengolahan data dibahas dengan mengacu pada tori-teori yang mendasari penelitian ini untuk mengetahui apakah hasilny mendukung teori atau tidak, sehingga dapat dibuat kesimpulan dan rekomendasi.

\section{HASIL DAN PEMBAHASAN}

Berdasarkan pengolahan data diperoleh hasil (a) skor rata-rata pada phonological awareness item Semantik $\left(\mathrm{X}_{1}\right)$ adalah 51,21 termasuk kategori sedang. (b) skor rata-rata pada phonological awareness item Sintaksis $\left(\mathrm{X}_{2}\right)$ adalah 10,55 termasuk kategori sedang. (c) skor rata-rata pada kemampuan menyelesaikan soal cerita matematika item Reading Comprehension a $\left(\mathrm{Y}_{1}\right)$ adalah 5,47 termasuk kategori sedang. (d) skor rata-rata pada kemampuan menyelesaikan soal cerita matematika item Computation $\left(\mathrm{Y}_{2}\right)$ adalah 4,21 termasuk kategori sedang. (e) skor rata-rata pada kemampuan menyelesaikan soal cerita matematika item Mathematic Comprehension $\left(\mathrm{Y}_{3}\right)$ adalah 6,95 termasuk kategori sedang.
Sedangkan besaran kontribusi masing-masing dalam penelitian ini adalah sebagai berikut: (1) Komponen semantik berpengaruh sebesar $\mathbf{2 1 . 9} \%$ terhadap kemampuan reading comprehension, (2) Komponen sintaksis berpengaruh sebesar $\mathbf{2 9 . 8 \%}$ terhadap kemampuan reading comprehension.(3) Komponen semantik dan sintaksis secara bersama-sama berpengaruh sebesar $\mathbf{5 1 , 7} \%$ terhadap kemampuan reading comprehension, (4) Komponen semantik berpengaruh sebesar 35.2 \% terhadap kemampuan computation, (5) Komponen sintaksis berpengaruh sebesar $\mathbf{2 1 . 7 \%}$ terhadap kemampuan computation, (6)Komponen semantik dan sintaksis secara bersamasama berpengaruh sebesar 56.9 \% terhadap kemampuan computation, (7) Komponen semantik berpengaruh sebesar 19.6\% terhadap kemampuan mathematic comprehension, (8) Komponen sintaksis berpengaruh sebesar $\mathbf{2 0 . 3 \%}$ terhadap kemampuan mathematic comprehension, (9) Komponen semantik dan sintaksis secara bersama-sama berpengaruh sebesar 39.9 \% terhadap kemampuan mathematic comprehension,

Reading comprehension berpengaruh sebesar $\mathbf{1 3 . 7}$ $\%$ terhadap kemampuan mathematic comprehension, (11) Computation berpengaruh sebesar $\mathbf{2 7 . 2 \%}$ terhadap kemampuan mathematic comprehension, (12) Reading comprehension dan computation berpengaruh sebesar $\mathbf{4 0 . 9 \%}$ terhadap kemampuan mathematic comprehension.

Secara gabungan dari pengaruh kedua variable dituangkan dalam table ringkasan berikut ini:

Tabel 1 : Rangkuman Hasil Pengujian Hipotesis.

\begin{tabular}{|c|l|c|c|c|c|c|l|}
\hline No. & \multicolumn{1}{|c|}{ Hipotesis } & F $_{\text {hitung }}$ & $\mathbf{F}_{\text {tabel }}$ & Sig & $\begin{array}{c}\text { Hasil } \\
\text { Pengujian }\end{array}$ & $\begin{array}{c}\text { Koefesien } \\
\text { Determinasi }\end{array}$ & Variabel Lain \\
\hline 1. & $\begin{array}{l}\text { Komponen semantic } \\
\text { (X1) dan sintaksis } \\
\text { (X2)secara bersama- } \\
\text { sama pengaruh } \\
\text { signifikan terhadap } \\
\text { kemampuan reading } \\
\text { comprehension(Y1) }\end{array}$ & $\mathbf{4 9 . 6 9 1}$ & $\mathbf{3 . 0 9 4}$ & $\mathbf{0 . 0 0 0}$ & Signifikan & $\mathbf{5 1 , 7} \%$ & $\mathbf{4 8 , 3 \%}$ \\
\hline
\end{tabular}


PEDAGOGIA : Jurnal IImu Pendidikan

\begin{tabular}{|c|l|l|l|l|l|l|l|}
\hline 2. & $\begin{array}{l}\text { Komponen semantik } \\
\text { (X1) dan sintaksis (X2) } \\
\text { secara bersama-sama } \\
\text { pengaruh signifikan } \\
\text { terhadapkemampuan } \\
\text { computation (Y2) }\end{array}$ & $\mathbf{6 1 . 6 2 9}$ & $\mathbf{3 . 0 9 4}$ & $\mathbf{0 . 0 0 0}$ & Signifikan & $\mathbf{5 6 , 9} \%$ & $\mathbf{4 3 , 1 \%}$ \\
\hline 3. & $\begin{array}{l}\text { Komponen semantic } \\
\text { (X1) dan sintaksis (X2) } \\
\text { secara bersama-sama } \\
\text { pengaruh signifikan } \\
\text { terhadapkemampuan } \\
\text { mathematic } \\
\text { comprehension(Y3) }\end{array}$ & $\mathbf{3 0 . 8 4 8}$ & $\mathbf{3 . 0 9 4}$ & $\mathbf{0 . 0 0 0}$ & Signifikan & $\mathbf{3 9 , 9} \%$ & $\mathbf{6 0 , 1 \%}$ \\
\hline 4 & $\begin{array}{l}\text { Reading } \\
\text { (Y1) comprehensiondan } \\
\text { computation(Y2) } \\
\text { pengaruh signifikan } \\
\text { terhadap kemampuan } \\
\text { mathematic } \\
\text { comprehension (Y3) }\end{array}$ & $\mathbf{3 2 . 0 9 1}$ & $\mathbf{3 . 0 9 4}$ & $\mathbf{0 . 0 0 0}$ & Signifikan & $\mathbf{4 0 , 9 \%}$ & $\mathbf{5 9 , 1 \%}$ \\
\hline
\end{tabular}

Hasil analisi jalur secara menyeluruh mengeni pengaruh kausal antara variabel phonological awareness (semantik dan sintakis) serta reading comprehension dan computation terhadap mathematic comprehension dapat dilihat pada gambar berikut ini:

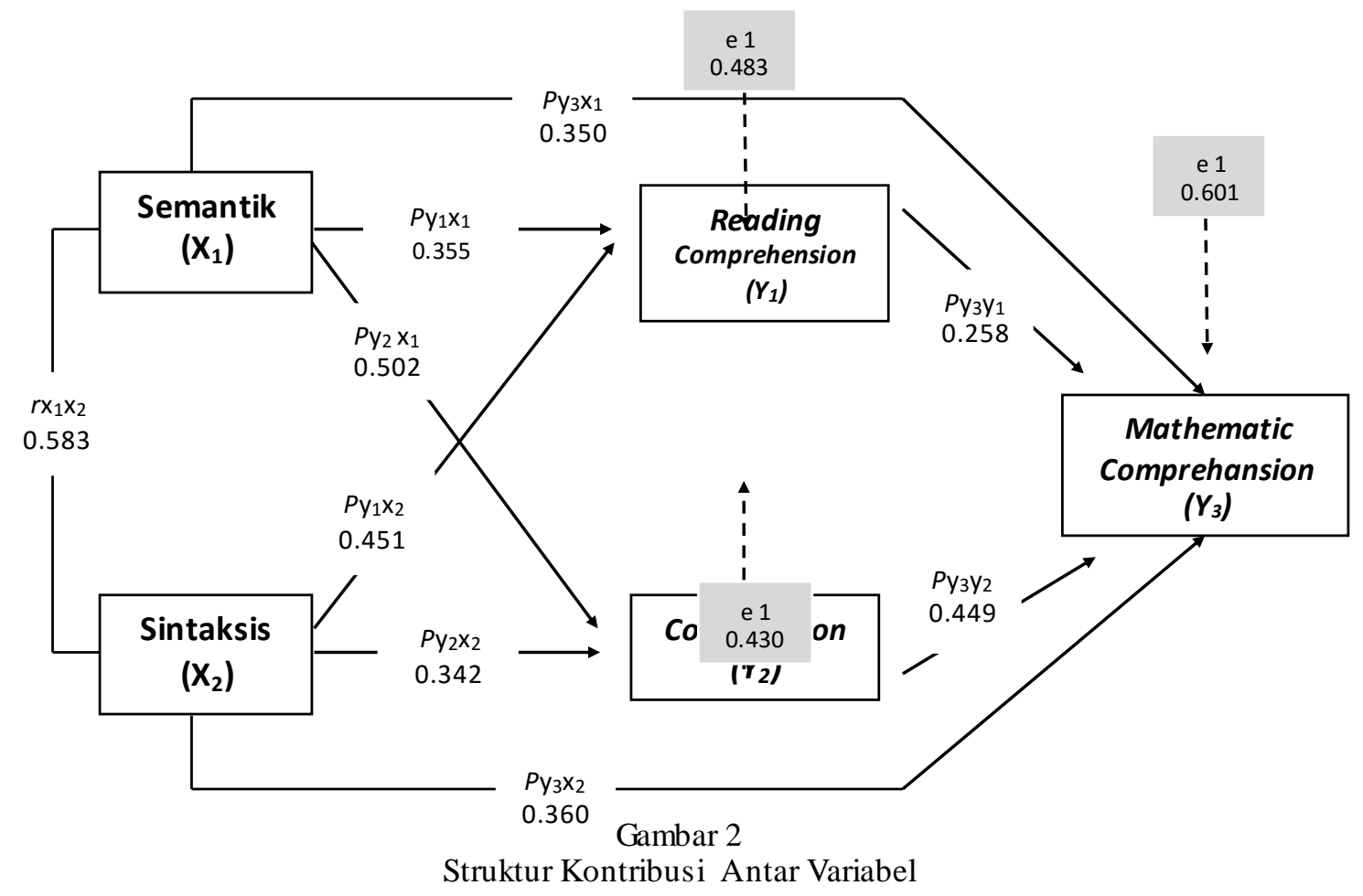




Hasil penelitian $\begin{array}{r}\text { mengungkap } \\ \text { kahwa salah satu } \\ \text { keterampilan }\end{array}$
penyelesaian soal cerita matematika yaitu
kemampuan reading comprehension,
computation dan
comprehension dipengaruhi $\begin{array}{r}\text { mathematic } \\ \text { signifikan oleh phonological awareness }\end{array}$
yang meliputi komponen semantik dan
sintaksis. Hasil ini sejalan dengan kajian
teoritis yang menyatakan bahwa
kegagalan individu dalam belajar
matematika sangat ditentukan oleh
kemampuan individu untuk melakukan
proses fonologis, yaitu kemampuan operasi mental yang diaplikasikan dalam bicara untuk merubah bentuk bunyi atau urutan bunyi (Robinson, Menchetti, dan Torgesen : 2002). Selain itu Lancaster dan Pope (1997) menyatakan bahwa pengaruh Phonological awareness aspek semantik dan sintaksis akan menentukan pemahaman struktur semantik dan sintaksis dalam struktur konsep matematika. Pada salah satu kemampuan yang harus dikuasai dalam penyelesaian soal cerita matematika yaitu membaca pemahaman (reading comprehension), hasil dari penelitian ini sejalan dengan pendapat yang dikemukakan oleh Johnson dan Medinus (1974) yang menyatakan bahwa phonological awareness merupakan satu stimulasi informasi yang paling berpengaruh terhadap keteramp Besaran pengaruh komponen phonological awareness terhadap reading comprehension secara parsial sebagai berikut: semantik $(21,9 \%)$ dan sintakis $(29,8 \%)$. Temuan tersebut dapat diartikan bahwa siswa yang dapat membedakan bunyi urutan kata atau kalimat akan meningkatkan kemampuan memahami isi dari sebuah bacaan atau disebut reading comprehension. Dari hasil tersebut yang lebih besar berpengaruh terhadap kemampuan reading comprehension adalah aspek sintaksis. Apabila melihat besaran pengaruh kedua komponen tersebut menunjukan dibawah $50 \%$ artinya pengaru besaran tidak terlalu kuat.

Hasil penelitian ini sejalan dengan hasil penelitian yang dilakukan oleh Rahmawati (2010) bahwa pengaruh komponen phonological awareness terhadap kemampuan reading comprehension pada siswa sekolah dasar yang tidak mengalami kesulitan membaca besarannya sebagai berikut : fonem ($4,6 \%)$, morfem $(1,9 \%)$, semantik $(5,4 \%)$ dan sintakis $(4,4 \%)$. Sedangkan pada siswa sekolah dasar yang mengalami kesulitan membaca besarannya sebagai berikut : fonem $(2,1 \%)$, morfem $(4,8 \%)$, semantik $(4,9 \%)$ dan sintakis $(0,2 \%)$. Besaran komponen semantik dan sintakis menunjukan angka yang lebih kecil bila dibandingakan dengan komponen yang lain. Apabila melihat perbandingan hasil penelitian pada komponen semantik dan sintakis menunjukan besaran pengaruh yang lebih besar adalah komponen sintakis yaitu 29,8\%. Hal ini berlawanan dengan hasil penelitian yang dilakukan Rahmawati (2010) dimana apabila hail penelitian yang dibandingkan hanya dua komponen yaitu semantik dan sintakis maka maka besaran pengaruh yang lebih besar adalah semantik 4,9\%. Temuan peneliti menunjukan hal sejalan dengan tahapan komponen dasar dalam proses pemahaman (decoding) bahasa yang dikemukakan oleh Chaer ( 2009) proses produktif (encoding) dimulai dari enkoding semantic menuju enkoding gramatikal dan berakhir di enkoding fonologis. Proses reseptif (decoding) dimulai dari decoding fonologis menuju dekoing gramatikal dan diakhiri dengan decoding semantik. Adapun prosesnya dapat dilihat pada gambar berikut ini : 


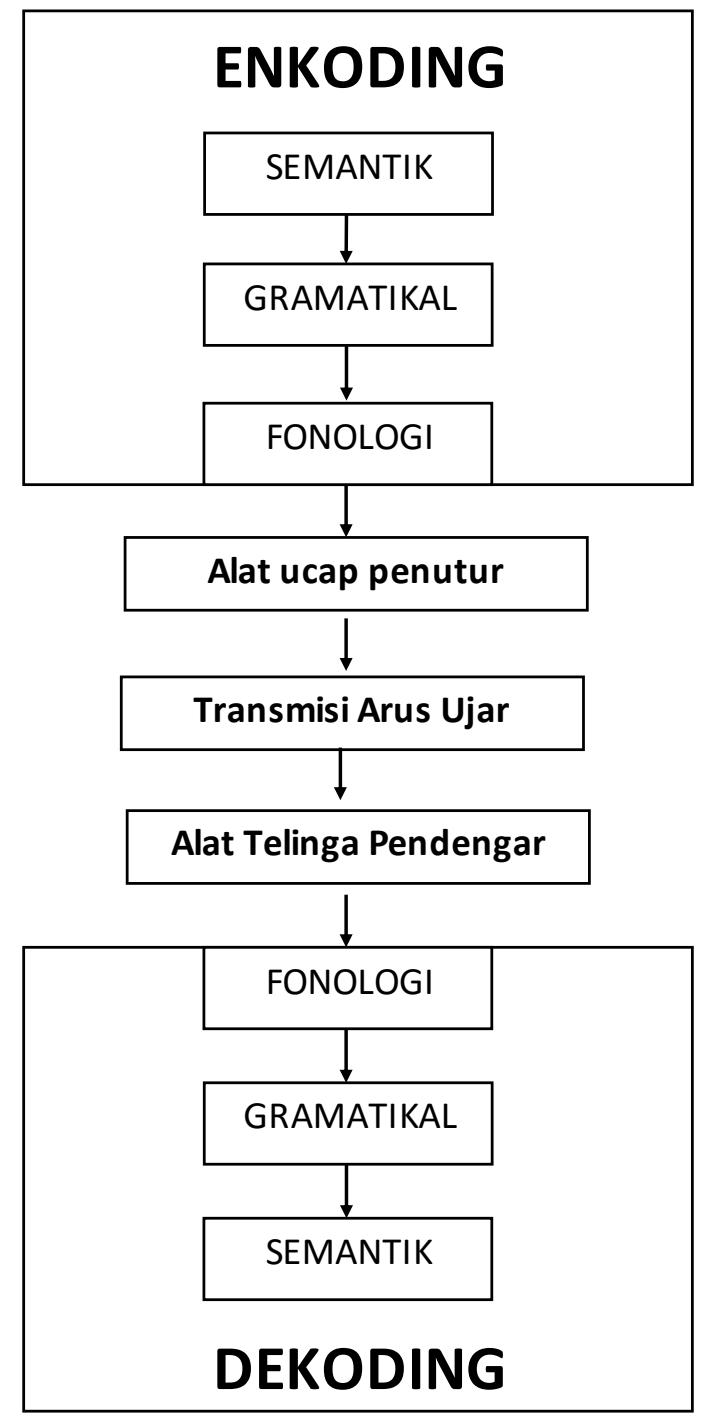

Gambar 4.9 Proses Berbahasa 
Sedangkan temuan pada aspek semantik menunjukan besaran yang lebih kecil yaitu 21,9\%. Hal ini diduga disebabkan sebagian dari siswa sebagai sampel dalam penelitian ini menggunkan bahasa sehari-hari bahasa sunda, sedangkan bahasa yang digunakan dalam instrumen yang digunakan bahasa Indonesia. Hal ini memungkinkan menjadi penyebab siwa memiliki interpretasi yang berbeda antara teks yang dibaca maupun kata yang didengar dengan pemikirannya, karena makna kata yang kurang dikenali atau kurang lazim digunakan oleh anak hari-hari sebagai ciri kurangnya perbendaharaan kata siswa.

Selain itu Elain itu Lancaster dan Pope (1997) menyatakan bahwa pengaruh Phonological awareness aspek semantik dan sintaksis akan menentukan pemahaman struktur semantik dan sintaksis dalam struktur konsep matematika. Adapun Struktur konsep matematika terdiri dari; (1) prinsip-prinsip dalam matematika, (2) prosedur-prosedur dalam matematika, dan (3) hubunganhubungan dalam matematika. Pada soal cerita makna kata menunjukan kuci sebuah operasi dasar matematika. Meskipun dalam proses sampai menemukan jawaban yang benar akan sangat berhubungan dengan penguasaan tentang konsepkonsep, prinsip-prinsip dan hubungan dalam matematika. Hal ini sejalan dengan pendapat Mulyono Abdurrahman (1999:254) yang mengatakan bahwa konsep menunjuk pada pemahaman dasar. Siswa mengembangkan suatu konsep ketika mereka mampu mengklasifikasikan atau mengelompokkan benda-benda atau ketika mereka dapat mengasosiasikan suatu nama dengan kelompok benda tertentu.

Penanaman konsep matematika pada anak yang paling mendasar adalah pemahaman tentang operasi hitung. Untuk mengajarkan konsep operasi hitung pada anak harus senantiasa memperhatikan tahap perkembangan berpikir anak. Pada tahap awal konsep operasi hitung yang diajarkan adalah konsep penjumlahan untuk bilangan natural (asli). Mengingat konsep matematika sesungguhnya bersifat abstrak, namun tahap berpikir anak untuk usia awal Sekolah Dasar biasanya masih bersifat kongkrit, maka guru atau orang tua harus berupaya untuk mengkonkretkan konsep yang abstrak tersebut agar anak tidak merasa kesulitan.

Konsep yang mendasari operasi hitung dasar yang meliputi penjumlahan (penambahan), pengurangan, perkalian dan pembagian (Ruseffendi, 1991:17). Belajar konsep merupakan unsur penting dalam matematika. Penguasaan terhadap banyak konsep, memungkinkan seseorang dapat memecahkan masalah dengan lebih baik sebab untuk memecah masalah perlu aturan-aturan, dan aturan-aturan tersebut didasarkan pada konsep-konsep yang dimiliki.

Dalam pemahaman matematika kemampuan membaca pemahaman sangat diperlukan hal ini sejalan dengan pendapat Mastie dan dan Jonson dalam Edi (2011:22) yang menyatakan bahwa pemahaman terjadi bila orang mampu mengenali, menjelaskan dan menginterpretasikan sesuatu atau masalah yang dihadapi.

Komponen sintaksis memiliki skor pengaruh yang lebih besar terhadap mathematic comprehension sama halnya yang terjadi pada reading comprehension. Keterampilan secara teknis dalam mengungkap kedua aspek ini diperlukan adanya membaca. Oleh karena itu membaca merupakan komponen penting dalam penyelesaian soal cerita matematika. Siswa yang mengalami hambatan membaca biasanya akan mengalami kesulitan juga dalam penyelesaian soal cerita matematika. Hal ini senada dengan pendapat Abdurrahman (1999:262) yang menyatakan anak yang mengalami kesulitan membaca akan 
mengalami kesulitan pula dalam memecahkan soal matematika yang berbentuk cerita tertulis.

Namun demikian pada soal cerita makna kata menunjukan kunci sebuah operasi dasar matematika. Meskipun dalam proses sampai menemukan jawaban yang benar akan sangat berhubungan dengan penguasaan tentang konsepkonsep, prinsip-prinsip dan hubungan dalam matematika. Hal ini sejalan dengan pendapat Abdurrahman (1999:254) yang mengatakan bahwa konsep menunjuk pada pemahaman dasar. Siswa mengembangkan suatu konsep ketika mereka mampu mengklasifikasikan atau mengelompokkan benda-benda atau ketika mereka dapat mengasosiasikan suatu nama dengan kelompok benda tertentu.

\section{E. SIMPULAN}

Dari penelitian yang telah dirumuskan diperoleh kesimpulan bahwa komponen phonological awareness (semantik dan sintaksis) baik secara bersamaan atau parsial memiliki pengaruh terhadap kemampuan penyelesaian soal cerita matematika yang meliputi (reading comprehension, computation dan mathematic comprehension). Pengaruh komponen phonological awareness, reading comprehension dan computation terhadap mathematic comprehension berpengaruh signifikan. Berdasarkan hasil pengolahan data dan analisis yang dilakukan menunjukan bahwa pengaruh komponen phonological awareness yang meliputi semantik dan sintaksis memberikan kontribusi yang signifikan yaitu: $\quad \mathbf{5 1 , 7} \%$ terhadap reading comprehension, $\mathbf{5 6 . 9} \%$ terhadap reading comprehension, dan $39.9 \%$ terhadap mathematic comprehension. Apabila dilaihat secara parsial kontribusi pengaruh secara parsial tidak melebihi 50\%. Namun demikian komponen phonological awareness tetap memberikan pengaruh yang signifikan terhadap kemampuan penyelesaian soal cerita matematika. Oleh karena itu upaya guru dalam peningkatan keterampilan penyelesaian soal cerita matematika memperhatikan prerequisite dari keterampilan-keterampilan yang harus dikuasai untuk menyelesaikan soal cerita matematika tersebut terutama pasa siswa kelas 1 sekolah dasar. Oleh karena itu guru hendaknya mengetahui keterampilanketerampilan yang harus dimiliki dalam tahapan penyelesaian soal cerita matematika secara mendalam. Selain itu apabila terdapat anak yang memiliki salah satu atau seluruhnya keterampilanketerampilan tersebut tidak dikuasai, maka harus diberikan latihan phonological awareness sebagai prasyarat dari keterampilan-keterampilan tersebut.

\section{F. REFERENSI}

Abdurrahman, M. (1999). Pendidikan Bagi Anak Berkesulitan Belajar. Jakarta: Rineka Cipta.

Aminudin. (2003). Semantik. Pengantar Studi tentang Makna. Bandung: Sinar Baru Algensindo.

Arikunto, S. (2006). Prosedur Penelitian Siuatu Pendekatan Praktek. Jakarta: Rineka Cipta.

Aryanti, Devi. (2004). Penerapan

Pendekatan SQ3.R Dalam

Meningkatkan Kemampuan Siswa

Menyelesaikan SoaL Cerita Pada

Pelajaran Matematik. Bandung:

Skripsi (tidak diterbitkan).

Carey, D. (1991). Number Sentences:

Linking Addition and Subtraction Word Problems and Symbols. Journal for Research in Mathematics Education, 22(4), 266-280.

Chaer, Abdul. (2002). Psikolinguistik

Kajian Teoritik. Jakarta: Rineka Cipta.

Edi, T. (2011). Peningkatan Pemahaman

Dan Komunikasi Matematis Serta

Kemandirian Belajar Siswa Sekolah

Menengah Atas Melalui Strategi Pq4r Dan Bacaan Refutation Text. 
Bandung : Disertasi SPs [Tidak diterbitkan]

Fitriani (2011). Upaya Meningkatkan Kemampuan Siswadalam Menyelesaikan Soal Cerita Matematika melalui Pendekatan Matematika Realistik. PGSD FIP UPI: Skrtipsi [Tidak diterbitkan]

Foster, E Matthew (2011). Indicators of Mathematics Skill Acquisition in Children with Mild Intellectual Disability: Phonological Awareness, Naming Speed, and Vocabulary Knowledge. Georgia State University: Phsychology Theses.

Gani, A.R (2010). Pengaruh Pembelajaran Metode Inkuiri Model Alberta Terhadap Kemampuan Pemahaman Dan Pemecahan Masalah Matematika Siswa Sekolah Menengah Atas. Sekolah Pascasarjana UPI: Disertasi [Tidak diterbitkan]

Geary, D.C. (2004). Mathematic and Learning Disability. Journal of Learning Disability. 37 (1), 3-15.

Gooding, S. (2009). Children's Difficulties with Mathematical Word Problems. Proceedings of the British Society for Research into Learning Mathematics 29(3). University of Cambridge

Goodstein, H.A. (1987). Are The Errors we see to errors? Errors Analysis in verbal problem solving. Topic in Journal Learning Disabelities. 37 (1), 3-15.

Herdiana, Heris. (2009). Pembelajaran Dengan Pendekatan Metaphorical Thinking Untuk Meningkatkan Kemampuan Pemahaman Matematik, Komunikasi Matematik Dan Kepercayaan Diri Siswa Sekolah Menengah Pertama. Bandung : Disertasi SPs UPI [Tidak Diterbitkan]

Lancaster, G., \& Pope, L. (1997). Working With Children's Phonology. Leicester City: Winslow Press, Ltd.
Lovitt,T.C. (1989). Introduction of Learning Disability. Boston: Allyn and Bacon.

McLoughlin, A.J. \& Lewis, B.R (1986). Assessing Special Student. Sydney: Merrill Publishing Company.

Ostrad, A.S (2011). Private Speech Use in Arithmetical Calculation: Contributory Role of phonological Awareness in Children With and Without Mathematical Difficultie. Journal of Learning Disability Dec 1 2011.

Rachmawati, S.A. (2010) Pengaruh Komponen Kesadaran Linguistik Terhadap Keterampilan Membaca Siswa Di Sekolah Dasar. Bandung: Tesis Sekolah Pascasarjana Universitas Pendidikan Indonesia.

Rahardjo, M. dan Waluyati, A (2011). Pembelajaran Soal Cerita Operasi Hitung Campuran di Sekolah Dasar. Jakarta: Kementrian Pendidikan Nasional.

Ramli (1993). Hubungan Penguasaan Kosa Kata dan Struktur Kalimat terhadap Pemahaman Informasi. Universitas Syah Kuala : Artikel

Riley, M.S., Greeno, J.G., \& Heller, J.I. (1983). Development of children ,s problem solving ability in arithmetic. Dalam H. Ginsburg (Ed.), The development of mathematical thinking (h. 153-156). Orlando, FL: Academic Press.

Robinson, C.S., Mancetti, B.M. dan Torgesen, J.K. (2000) Toward a Two Factor Theory of One Tpe Mathematic Disabilities. Journal Learning Disabilities Research \& Practice. 17 (2), 81-89

Ruseffendi, E.T. (1988). Pengajaran Matematika Modern dan Masa Kini. Bandung: Tarsito.

Ruseffendi, E.T. (1991). Pengantar kepada Membantu Guru Mengembangkan Kompetensinya dalam Pengajaran Matematika 
untuk Meningkatkan CBSA.

Bandung: Tarsito.

Santoso, Budi. (2008). Pengaruh

Kemampuan Phonological

Processing terhadap Keterampilan

Dasar Matematika. Bandung: Tesis

(tidak diterbitkan).

Saptuju. (2005). Meningkatkan

Kemampuan Siswa SMP dalam

Menyelesaikan Soal Cerita Melalui

Belajar Kelompok Kecil Dengan

Pendekatan Problem Solving.

Bandung: Tesis UPI (Tidak diterbitkan)

Shaywitz, S (2006). Overcoming Dyslexia a New and Complete Science Base Programfor Reading Problemat Any Level. New York: Alfred.

Solso L. R. dkk (2007). Psikologi Kognitif. Jakarta: Erlangga

Somantri, Sucihati. (2005). Psikologi Anak Luar Biasa. Bandung: Reflika Aditama

Subyakto, N.U (1988). Psikolinguistik :

Suatu Pengantar. Jakarta:

Departemen Pendidikan dan

Kebudayaan

Sumarmo, U. (2002) Alternatif

Pembelajaran Matematika Dalam

Menerapkan Kurikulim Berbasis

Kompetensi. Bandung : Makalah

Dosen MIPA UPI

Syafri, Ahmad (2001). Mengatasi

Kesulitan Siswa Dalam

Menyelesaikan Soal Cerita Satu

Langkah di Kelas II SD. Malang :

LPTK dan ISPI

Spector, J.E. (1992). Predicting Progress

in Beginning Readig: Dynamic

Asesment of Phonemic Awareness,

Journal of Education Psychology 84, $64-370$.

Tarigan, H.G. (2008) Menulis Sebagai

Keterampilan Berbahasa.

Bandung:Angkasa.

Torabipou, A., Baharloue, N, \&. Tazhibil, M (2011). The relationship between phonemic awareness and mathematical skills in first-grade students. Journal of Research In

Rehabilitation Sience Vol.7 No.1

Isfahan University of Medical

Sciences.

Torgessen, J.K and Mathes P.G. (1998).

Wahat Every Teacher Hould Know

about Phonologycal Awareness,

Article Florida Department of

Education Division of Public

Schools and Community Education

Bureau of Instructional Support and

Community Services.

Wagner, R. K., Torgesen, J.K., \&

Rashotte, C.A. (1999).

Comprehensive Test of Phonological

Processes. Austin, TX: PRO-ED

Publishing, Inc. 012] 